\title{
Long-term decline of the European wild rabbit (Oryctolagus cuniculus) in south-western Spain
}

\author{
Sacramento Moreno ${ }^{\mathrm{A}, \mathrm{F}}$, Juan F. Beltrán ${ }^{\mathrm{B}}$, Irene Cotilla ${ }^{\mathrm{C}}$, Beatriz Kuffner ${ }^{\mathrm{D}}$, Rafael Laffite ${ }^{\mathrm{A}}$, \\ Gloria Jordán ${ }^{\mathrm{E}}$, José Ayala ${ }^{\mathrm{A}}$, Carmen Quintero ${ }^{\mathrm{A}}$, Antonio Jiménez ${ }^{\mathrm{A}}$, Francisca Castro ${ }^{\mathrm{C}}$, \\ Sonia Cabezas ${ }^{\mathrm{A}}$ and Rafael Villafuerte ${ }^{\mathrm{C}}$ \\ ADepartment of Applied Biology, Estación Biológica de Doñana CSIC, Avda. María Luisa s/n, 41013 Seville, Spain. \\ ${ }^{B}$ Department of Physiology and Zoology, University of Seville, Avda. Reina Mercedes 6, 41012 Seville, Spain. \\ CInstituto de Investigación en Recursos Cinegéticos (CSIC-UCLM-JCCM), Ronda de Toledo s/n, 13071 \\ Ciudad Real, Spain. \\ DUniversidad Nacional de Córdoba, Avda. Ciudad de Valparaíso s/n, 5000 Córdoba, Argentina. \\ EFundación General de la Universidad de Castilla - la Mancha, C/Altagracia, 5013071 Ciudad Real, Spain. \\ FCorresponding author. Email: smoreno@ebd.csic.es
}

\begin{abstract}
The European wild rabbit (Oryctolagus cuniculus) is a species native to the Iberian Peninsula, where it was once extremely abundant. It is considered the most important prey item for the peninsula's assemblage of Mediterranean vertebrate predators, which includes two endangered specialist rabbit feeders, the Spanish imperial eagle (Aquila adalberti) and the Iberian lynx (Lynx pardinus). However, rabbit population trends in Spain have not been accurately documented. In the present study, we analysed trends in a population of European rabbits monitored over 23 years in the Doñana National Park, home to one of the most diverse and densest predator communities in Europe. Rabbit abundance and population trends were estimated using roadside counts. Results show that the rabbit population declined sharply by $\sim 60 \%$ during the first wave of epizootic rabbit hemorrhagic disease (RHD) in 1990. Since then, rabbit numbers have declined at a relatively constant rate and the species has become progressively scarcer in the area. The current population is less than $10 \%$ of that before the arrival of RHD. However, after the RHD epizootic we observed increasing intra-annual population recruitment. We hypothesise that density-dependent factors caused by enzootic viral diseases (myxomatosis, RHD) and higher predation of rabbits are the main factors preventing recovery of rabbit numbers. The effects of a decline in the prey species on the ecology of sympatric rabbit predators are discussed, and measures to improve ongoing rabbit conservation efforts are suggested.
\end{abstract}

\section{Introduction}

The European wild rabbit (Oryctolagus cuniculus) is endemic to the Iberian Peninsula, where it was once present in such high densities that Strabo described it as a pest in the first century AD (García y Bellido 1986). The abundance and wide distribution of this species throughout the Iberian Peninsula contributed greatly to the shaping of Iberian biocenoses (Valverde 1967). In these ecosystems the European rabbit is one of the most important trophic links for converting plant to animal biomass (Valverde 1967; Delibes and Hiraldo 1981) and in Spain it is the staple prey of 29 predator species (Delibes and Hiraldo 1981), including the Iberian lynx (Lynx pardinus) and the Spanish imperial eagle (Aquila adalberti), two endangered species that are highly dependent on rabbits (Ferrer and Negro 2004). Consequently, the European rabbit is considered a keystone species in Iberian Mediterranean ecosystems (Delibes-Mateos et al. 2007).

The central position of the European rabbit in Iberian ecosystems was emphasised in the second half of the twentieth century by the consequences of the introduction of the viral disease myxomatosis. This disease caused a sharp decline in rabbit populations, and an associated dramatic decrease in the abundance of several rabbit predators (Valverde 1960a, 1967).
Estimates of rabbit mortality resulting from myxomatosis approaching 100\% were common in several European and nonEuropean countries, where a series of wide-ranging ecological repercussions of the decline in rabbit numbers were also reported (see Sumption and Flowerdew 1985). Similar population crashes almost certainly occurred on the Iberian Peninsula, but there is no scientific information on changes in rabbit populations caused by myxomatosis, or their ecological consequences. Empirical information shows that the disease became endemic and, although rabbit mortality in the field fell progressively over the following decades, populations have never returned to their former levels (Rosell 2000).

At the end of the 1980s another viral disease, rabbit hemorrhagic disease (RHD), caused a wave of rabbit mortality that rapidly spread throughout the Iberian Peninsula, severely reducing rabbit numbers (Villafuerte et al. 1995). Mortality rates produced by the first wave of this new disease were estimated at $\sim 50-70 \%$ in some areas of Spain (Villafuerte et al. 1994, 1995). RHD became enzootic and 5 years later estimated mortalities were close to 30\% (Villafuerte et al. 1995). Some information on rabbit abundance was available for several areas of Spain a 

few years after the RHD outbreak (Blanco and Villafuerte 1993; Calvete et al. 2002; Palomares 2003), or could be inferred by analysing data up to 2002 (the last year of available information) on the number of rabbits estimated to be hunted in each Spanish province based on the Ministry of Agriculture reports (Piorno 2006; Virgós et al. 2007).

Significant changes in predator communities on the Iberian Peninsula have been reported (Viñuela and Veiga 1992; Fernández 1993; Ferrer and Donázar 1996; Fedriani et al. 1998; Zapata et al. 1998; Martínez and Zuberogoitia 2001; Palomares et al. 2001; Viñuela and Villafuerte 2003) and attributed to decreases in rabbit populations owing to RHD. However, none of these studies quantified the real rabbit decline.

Long-term studies of rabbit populations can provide very useful information on trends over time, and may reveal or explain predator-related interactions. These studies are especially valuable in protected areas where predator species dependent on rabbits are highly threatened. This is the case in the Doñana National Park (south-western Iberian Peninsula), which has one of the densest and most diverse predator communities in Europe (Valverde 1958, 1960b, 1967; Kufner 1986). As a protected area, the park has provided the opportunity to collect long-term data on both rabbit abundance and rabbit predators in an area that has not been hunted. Doñana National Park is also one of the few places where two highly endangered species, the Iberian lynx and the Spanish imperial eagle, still coexist.

In this paper we present the trends in rabbit populations in Doñana National Park over 23 years (January 1984 to October 2006). Our aims were (a) to document long-term trends in a wild rabbit population in a Mediterranean habitat before and after the establishment of RHD, (b) to explore causes and consequences of population trends of this keystone species, and (c) to propose measures for ongoing and future management and conservation of wild rabbits.

\section{Materials and methods}

The study was carried out in the Doñana National Park $\left(37^{\circ} 10^{\prime} \mathrm{N}\right.$, $6^{\circ} 23^{\prime} \mathrm{W}$ ) (Fig. 1). The park covers $\sim 550 \mathrm{~km}^{2}$ on the north bank at the mouth of the Guadalquivir River. The climate is Mediterranean, with hot dry summers (average August temperature $25^{\circ} \mathrm{C}$ ) and cool, wet winters (average January temperature $10^{\circ} \mathrm{C}$, average annual precipitation $600 \mathrm{~mm}$ ). There are three main biotopes in the park: sand dunes, marshlands and scrubland (Valverde 1958). Rabbits are most abundant in the scrubland (Moreno and Villafuerte 1995).

Between January 1984 and October 2006, rabbit counts were carried out $1 \mathrm{~h}$ before dusk from vehicles travelling at $20 \mathrm{~km} \mathrm{~h}^{-1}$ along a fixed 14.7-km transect across the scrubland near the marshland (Fig. 1). The transect was mainly along breaks, guaranteeing a consistent wide and stable area clear of scrub and forbs, and enabling observation of rabbits. Although carried out over a long period, five observers performed most of the censuses; hence interobserver variations in the data should be minor. Rabbit counts were typically conducted monthly on three consecutive days at dusk, a time when rabbit activity is least influenced by seasonal or environmental factors (Villafuerte et al. 1993). An index of known abundance (kilometric abundance index, KAI) of rabbits was calculated by averaging the number of rabbits counted per kilometre for all censuses within each month. Censuses were not performed in some months, with the largest gap occurring in 1990, when no counts were made. During 1985, counts were conducted only every 2 months.

In general, the annual maximum rabbit abundance $\left(\mathrm{KAI}_{\max }\right)$ was reached after the breeding season (usually June), and minimum annual rabbit abundance $\left(\mathrm{KAI}_{\min }\right)$ typically occurred in January, although in some cases it corresponded to the previous December (Beltrán 1991).

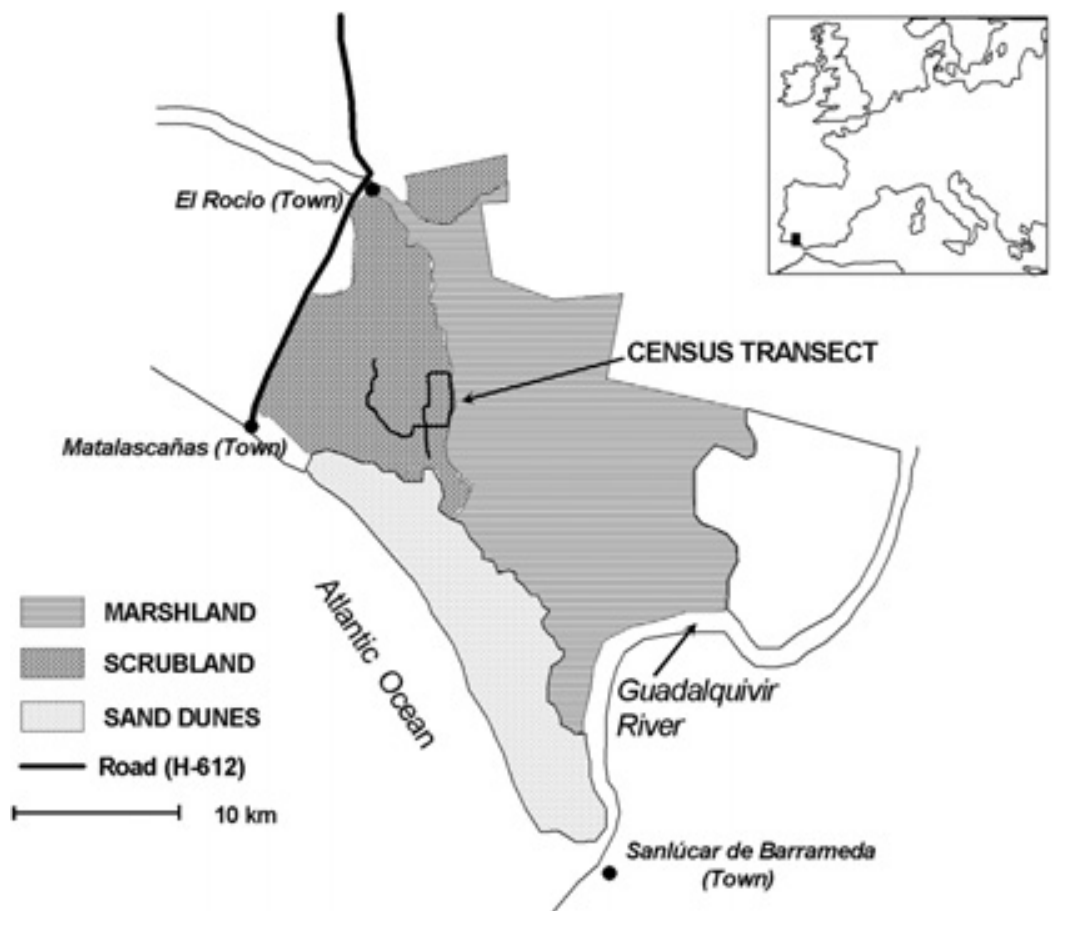

Fig. 1. Location and main biotopes of the Doñana National Park (south-west Iberian Peninsula), and the location of the transect used for censuses of the European rabbit. 
Although we used the KAI as a reliable estimate of rabbit abundance (Ballinger and Morgan 2002; Poole et al. 2003) and trends in rabbit populations in the Doñana National Park, from 1989 we also recorded the perpendicular distance of each rabbit from the transect line to enable rabbit densities to be estimated using DISTANCE software (Thomas et al. 1998). To avoid inaccuracies arising from small sample sizes (Harris and Burnham 2002), we performed density estimates in some years only in June, when populations were at their highest levels.

Intra-annual population growth (IPG) was calculated each year to detect population increases due to reproduction. The IPG for a given year (i) was calculated by dividing $\mathrm{KAI}_{\min (i)}$ by $\mathrm{KAI}_{\max (\mathrm{i})}$. The index of inter-annual population variation from the end of one breeding season until the start of the next $\left(\operatorname{IPD}_{(\mathrm{i})}\right)$ was determined from the expression $\mathrm{KAI}_{\max (\mathrm{i})} / \mathrm{KAI}_{\min (\mathrm{i}+1)}$. Finally, because both slow and sudden changes in rabbit abundance have been associated with rainfall (Villafuerte et al. 1997; Palomares 2003), we also analysed the relationship between annual rainfall (starting in September, data obtained from a nearby meteorological station, available at http://www-rbd.cbd. csic.es/seguimiento/mediofisico.htm) and the indices of abundance, and population growth and decline in the following calendar year.

STATISTICA software (v.6, StatSoft Inc.) was used to assess differences in populations before and after the establishment of RHD (Mann-Whitney U test), and to determine annual tendencies (Spearman correlations). The year of arrival of the disease in the study area (1990) was not included in the analyses.

\section{Results}

During the 23-year study period (1984-2006), there was a dramatic change in KAI value (Fig. 2). In particular, rabbit abundance declined sharply beginning in 1990, the year in which RHD reached the study area. Both $\mathrm{KAI}_{\max }$ and $\mathrm{KAI}_{\min }$ were significantly lower after the arrival of RHD (Mann-Whitney test, $\mathrm{Z}=3.50, n=21, P<0.001$ for both parameters). Estimated mean maximum monthly rabbit density declined from 8.6 rabbits ha ${ }^{-1}$ in June 1989 to 6.7 rabbits ha $^{-1}$ in June 1990 (just a few months

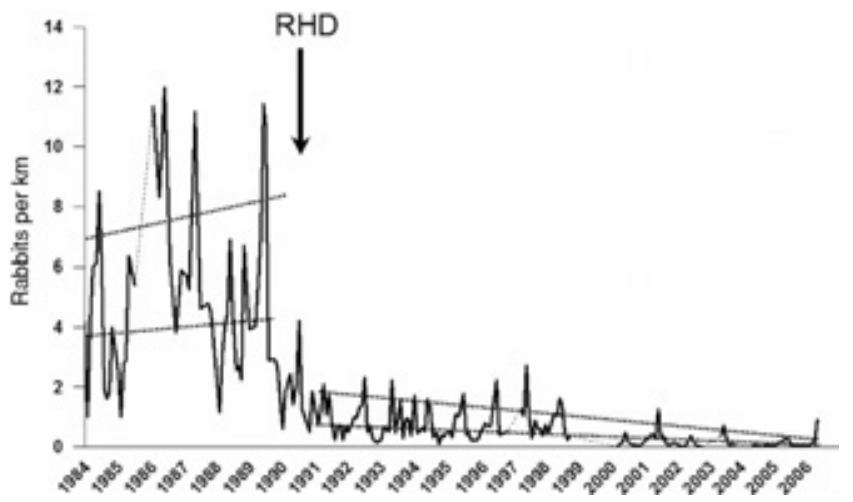

Fig. 2. Trends in rabbit abundance (kilometric abundance index, KAI) in the Doñana National Park during a 23-year period (January 1984 - October 2006). The arrow indicates the date of the first outbreak of viral rabbit hemorrhagic disease (RHD) in the area. Regression lines were fitted to show $\mathrm{KAI}_{\text {max }}$ and $\mathrm{KAI}_{\min }$ trends before and after the arrival and establishment of RHD. after the arrival of the disease). It subsequently fell further to 1.5 rabbits ha ${ }^{-1}$ and rarely exceeded 2 rabbits ha ${ }^{-1}$ thereafter.

Before the first RHD outbreak (1984-1989) the trends for $\mathrm{KAI}_{\max }$ and $\mathrm{KAI}_{\min }$ showed no statistical variation over time $(r=0.200, n=6, P=0.704$; and $r=0.143, n=6, P=0.787$; respectively) (Fig. 2). After establishment of RHD (19912006), however, a progressive and significant decline occurred in $\mathrm{KAI}_{\max }$ and $\mathrm{KAI}_{\min }(r=-0.868, n=15, P<0.001$; and $r=$ $-0.839, n=15, P<0.001$, respectively) (Fig. 2).

The annual indices of population growth and decline (IPG and IPD) were significantly different before and after the establishment of RHD (Mann-Whitney tests: $\mathrm{Z}=-3.27, n=21$, $P=0.001$ for IPG; $\mathrm{Z}=-2.55, n=21, P=0.011$ for IPD). Population growth showed an inverse relationship with rabbit abundance just at the start of reproduction $\left(\mathrm{KAI}_{\min }: r=-0.896\right.$, $n=21, P<0.001$ ) (Fig. 3a). The same negative relationship was found between the maximum abundance reached after reproduction and the population decline $(r=-0.583, n=21$, $P=0.006$ ) (Fig. 3b).

The seasonal pattern of rabbit abundance differed little before and after the establishment of RHD despite the huge differences in rabbit numbers during these two periods (Fig. 4). Rabbit abundance followed the same seasonal pattern throughout the area, with population peaks occurring in early summer, and minimum values occurring in late autumn.

Annual rainfall was not correlated with rabbit abundance in the period before the establishment of RHD ( $r=-0657, n=6$, $P=0.156$ for $\mathrm{KAI}_{\max }$ and $r=0.003, n=6, P=0.957$ for $^{\mathrm{KAI}_{\min }}$ )
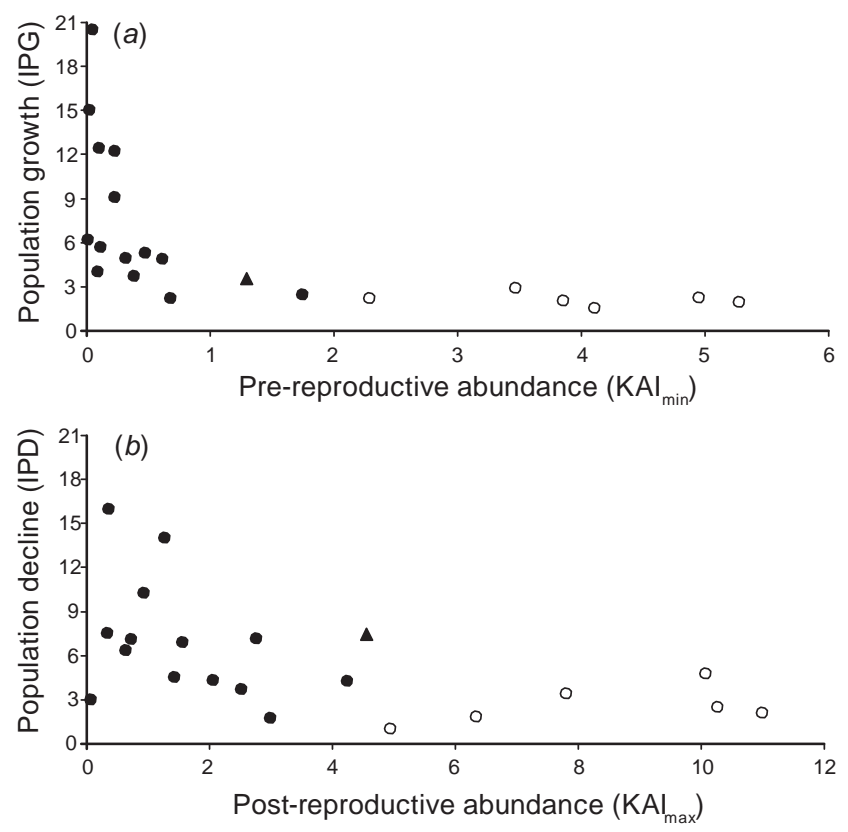

Fig. 3. (a) Intra-annual rate of population growth (IPG) compared with the abundance of rabbits before reproduction $\left(\mathrm{KAI}_{\min }\right)$. (b) Intra-annual rate of population decline (IPD) compared with the abundance of rabbits after reproduction $\left(\mathrm{KAI}_{\max }\right)$. Open circles correspond to those years before the first RHD outbreak (1990, black triangle), while black circles represent the years after the RHD outbreak. 


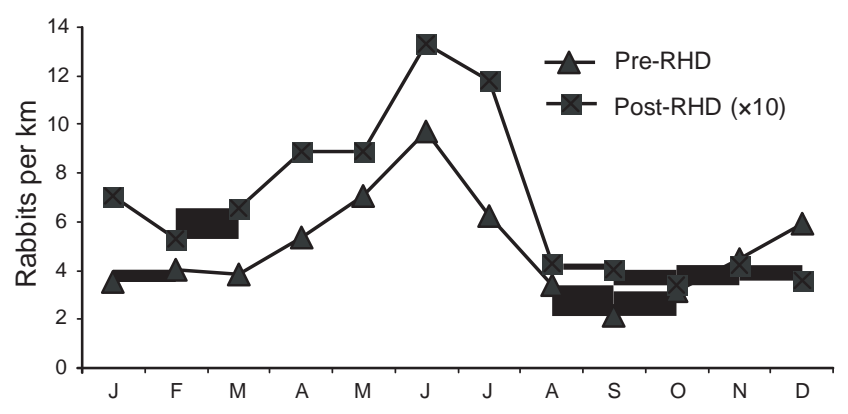

Fig. 4. Seasonal abundance patterns in rabbits in Doñana National Park before (triangles) and after $(\times 10)$ (squares) the first RHD outbreak in the park. Lines represent trends.

or in the period following establishment $(r=-0.04, n=15, P=$ 0.899 for $\mathrm{KAI}_{\max }$ and $r=0.021, n=15, P=0.939$ for $\mathrm{KAI}_{\min }$ ).

\section{Discussion}

The decline in wild rabbit numbers in the Iberian Peninsula, especially since the introduction of RHD in 1990, has had many negative consequences (i.e. Delibes-Mateos et al. 2007). In the present study, we analysed trends in rabbit numbers over 23 years in the Doñana National Park, in an effort to quantify the rabbit decline in a Mediterranean population. Although indices of kilometric abundance have commonly been used to explore rabbit abundance in Spain (i.e. Villafuerte et al. 1994; Ontiveros and Pleguezuelos 2000; Palomares 2001, 2003), this methodology is considered a controversial tool for evaluating the abundance or density of a species. Most critics of this approach cite variations in the detectability of animals over space and time as key problems (Thompson et al. 1998; Anderson 2001; Marchandeau et al. 2006), while others question its validity for density estimation (Engeman 2005). In our study, several factors should have contributed to the stability of rabbit detectability and the consistency of the observations: all censuses were carried out along the same 14.7-km transect; a small number of experienced observers performed the censuses; the censuses were made along firebreaks whose width was maintained over time; and the censuses were performed at dusk, when rabbit activity aboveground is least affected by environmental factors (Villafuerte et al. 1993). In fact, the KAI values obtained during consecutive censuses were quite stable, with a coefficient of variation of only $3.8 \pm 2.3 \%$. Therefore, although KAI has shortcomings as a tool for determining rabbit densities, or for comparing abundances among populations, it was a valid approach for us to document the long-term trends in rabbit abundance in our study area.

Our results show that rabbit abundance remained more or less stable from 1984 until 1990, at which point rabbit numbers declined rapidly and dramatically. From 1991 to 2006, a slow but continuing decline was observed. In March 1990, RHD entered the study area and produced 55\% mortality, as calculated by radio-tracking studies (Villafuerte et al. 1994). This dramatic decline was reflected in our road census data, where the KAI value decreased by $55.3 \%$ (5.48 to 2.45 rabbits km${ }^{-1}$ ) between April 1989 (one year before the first outbreak) and April 1990. Rabbits in the study area have not recovered to their previous levels since the arrival of RHD; rather, a slight but steady decrease in overall numbers has been observed, paralleling results from Australia, France and New Zealand (Saunders et al. 1999; Marchandeau et al. 2000; Holden and Mutze 2002; Edwards et al. 2002; Norbury et al. 2002).

Mutze et al. (2002) speculated that the introduction of RHD may cause a shift in rabbit breeding patterns, encouraging further studies to investigate this possibility. In contrast, we have shown that after the outbreak of RHD, rabbit population dynamics maintained the same seasonal pattern, with peak values in June owing to reproductive recruitment, and minimum levels in autumn (Beltrán 1991). A second, lower peak in abundance was observed in December (Beltrán 1991).

It is noteworthy that despite much lower population numbers than in the pre-RHD period, between 1991 and 2006 the seasonal population growth from winter to late spring was higher. Thus, as rabbit abundance before reproduction progressively dropped, population growth rates rose. This density-dependent response is known to occur in mammals (Delany 1974; Rödel et al. 2004) and is related to a density-dependent adjustment of individual reproduction, or is the result of a lower proportion of individuals living in unfavourable sites. However, despite their higher growth potential, overall net population numbers continued to decline slightly. Therefore, other factors seem to be preventing the recovery of rabbit populations to former levels, since population decline was higher while the abundance after reproduction was lower, particularly before the establishment of RHD.

Given that hunting is forbidden within the Doñana National Park, the main factors influencing rabbit populations include (1) bad weather (Palomares 2003), (2) net loss of favourable habitat (Moreno and Villafuerte 1995), (3) mortality caused by myxomatosis and RHD (Calvete et al. 2002), and (4) changes in the impact of predation on rabbit populations.

We specifically tested for the influence of precipitation on rabbit abundance during our study period, and observed no significant relationship before or after the establishment of RHD. Therefore, our findings indicate that precipitation did not cause the changes in population levels, as has been suggested for an area nearby (Palomares 2003). Although some net loss of favourable habitat has occurred, the area still offers enough resources for ensuring a high rabbit carrying capacity (Lombardi et al. 2003). The recidivist mortality from myxomatosis and RHD is an important density-dependent factor that explains the observed trends in rabbit populations in Spain and Australia (Cooke 2002). Although no data exist for the Doñana National Park regarding mortality from disease or disease interactions, these factors may partially explain the negative rabbit population trends observed in the area in spite of the positive increase in the intra-annual rate of population growth (Mutze et al. 2002).

Despite the importance of disease in explaining rabbit population trends, the impact of predation must also be considered as a factor affecting population recovery. Studies in the park show that opportunistic and specialist predators have responded differently to the recent collapse in rabbit numbers caused by RHD. Opportunistic predators such as the badger (Meles meles), red fox (Vulpes vulpes), Egyptian mongoose (Herpestes ichneumon), common genet (Genetta genetta) and booted eagle (Hieraaetus pennatus) all decreased their consumption of 
rabbits by $50-80 \%$, but at the same time increased in abundance (Rau 1987; Delibes et al. 1992; Fedriani et al. 1998). For example, red fox numbers increased five-fold between 1987 and 1993 (Travaini et al. 1997). Similar results were reported for black and red kites (Milvus migrans and M. milvus) (Viñuela and Veiga 1992; Hiraldo et al. 1997; Forero et al. 2002). All of these species seem to show a functional response to depletion in rabbit populations (Solomon 1949; O’Donoghue et al. 1998).

Under these circumstances, the RHD-induced crash in rabbit numbers, and its consequences for rabbit populations, may also be explained by the so-called 'predator pit' theory. This states that after a sudden population crash, numbers will be kept stable but at low densities by predator regulation, even if the cause of initial reduction is removed (Trout and Tittensor 1989; Pech et al. 1992). If this were the case, rabbit numbers would have been expected to be low but to have remained at a stable density. However, in the present situation the RHD is still killing susceptible animals recruited each year after reproduction, and consequently the population is progressively declining, although probably affected by predator regulation.

There are many reported conservation consequences of rabbit scarcity. For instance, neither of the park's two most endangered species, the Iberian lynx and Spanish imperial eagle, has significantly changed diet, and rabbits continue to represent a large proportion of their prey (Delibes et al. 2000; Ferrer 2001). However, since 1990 the distribution range of the Iberian lynx in Spain has shrunk by 88\% (Rodríguez and Delibes 2003) and the breeding success of the species in the park dropped to below 50\% (Ferreras 2001). Furthermore, the number of pairs of Spanish imperial eagles, the number of breeding pairs and the numbers of birds fledged in the National Park have all decreased since the outbreak of RHD (from 15 to 7; from 15 to 5; and from 14 to 2, respectively) (Natural Process Monitoring Team of Doñana Biological Station, CSIC). Likewise, mortality rates of Spanish imperial eagles increased by 300\% between 1999 and 2003, and the probability that this species will become extinct in the Doñana National Park over the next 5 years is thought to be $\sim 95 \%$ (M. Ferrer, pers. comm.). These patterns fit well with the expected numeric response for specialist predators (Elton and Nicholson 1942).

In conclusion, given that mortality and breeding success of these specialist predators depends greatly on rabbit abundance (Ferrer 2001; Rodríguez and Delibes 2004), the general response to rabbit depletion in the Doñana National Park (and probably in other areas of Spain) has been a decrease in specialist rabbit predator numbers. In addition, because the predation pressure on rabbits from generalist carnivores and raptors is higher than that from specialist predators (Villafuerte 1994), rabbit abundance is expected to remain low and decline slowly. If the rabbit population is trapped in the 'predation pit', recovery to pre-RHD abundance levels is unlikely (Banks 2000; Marchandeau et al. 2000). In these circumstances only exceptionally high rabbit recruitment or artificially reduced predation may enable rabbits to escape predator regulation (Pech et al. 1992). Although management to increase rabbit numbers has been undertaken in the park (Moreno and Villafuerte 1995; LIFE 2002; Moreno et al. 2004), no positive outcome is yet evident. Because diseases are difficult to manage or control in the wild (Calvete et al. 2004), any effective future effort to increase rabbit populations should be based on reliable information that includes simultaneous data on population dynamics and field epidemiology (Cooke 2002). Future studies in this area should aim to gather such data and include comparative studies on differential predation impact. This knowledge will also be helpful for revealing the relative importance of factors influencing trends in rabbit populations after the arrival of RHD. Gathering comparative, long-term rabbit-abundance data in other areas of Spain is also of critical importance. This will require a unique methodology to assess comparable and precise rabbit-abundance data, along with concerted efforts from wildlife managers and scientists to generate such data.

\section{Acknowledgements}

We thank Drs J. J. Negro, M. Ferrer, J. Litvaitis and P. Palomares for revision of a previous version of this manuscript. We also thank two anonymous referees whose comments helped us improve the manuscript. The study was funded by several different projects including 1FD1997-0789, BOS20012391-C02-01, REN2001-0448, PAI06-0170, FAU2006-0014-C02-02, and CGL2005-02340. This work was undertaken in accordance with the laws of Spain.

\section{References}

Anderson, D. R. (2001). The need to get the basics right in wildlife field studies. Wildlife Society Bulletin 29, 1294-1297.

Ballinger, A., and Morgan, D. G. (2002). Validating two methods for monitoring population size of the European rabbit (Oryctolagus cuniculus). Wildlife Research 29, 431-437. doi:10.1071/WR01055

Banks, P. B. (2000). Can foxes regulate rabbit populations? Journal of Wildlife Management 64, 401-406. doi:10.2307/3803238

Beltrán, J. F. (1991). Temporal abundance patterns of the wild rabbit in Doñana, SW Spain. Mammalia 55, 591-599.

Blanco, J. C., and Villafuerte, R. (1993). Factores ecológicos que influyen sobre las poblaciones de conejo. Efectos de la enfermedad hemorrágico vírica. TRAGSA, Madrid Spain.

Calvete, C., Estrada, R., Villafuerte, R., Osacar, J. J., and Lucientes, J. (2002). Epidemiology of viral haemorrhagic disease and myxomatosis in a free-living population of wild rabbits. Veterinary Record 150, 776-782.

Calvete, C., Estrada, R., Lucientes, J., Osácar, J. J., and Villafuerte, R. (2004). Effects of vaccination against viral haemorrhagic disease and myxomatosis on long-term mortality rates of European wild rabbits. Veterinary Record 155, 388-392.

Cooke, B. D. (2002). Rabbit haemorrhagic disease: field epidemiology and the management of wild rabbit populations. Revue Scientifique et Technique. Office International des Epizooties 21, 347-358.

Delany, M. J. (1974). 'The Ecology of Small Mammals.' Studies in Biology $n^{\circ}$ 51. (E. Arnold Ltd.)

Delibes, M., and Hiraldo, F. (1981). The rabbit as prey in the Iberian Mediterranean ecosystems. In 'Proceedings of the World Lagomorph Conference.' (Eds K. Myers and C. D. MacInnes.) pp. 614-622. (University of Güelph \& Wildlife Research, Ministry of Natural Resources: Ontario.)

Delibes, M., Ferreras, P., Travaini, A., and Laffite, R. (1992). Evolución de las poblaciones de carnívoros del Parque Nacional de Doñana. Informe Final. Estación Biológica de Doñana (CSIC), Sevilla Spain.

Delibes, M., Rodríguez, A., and Ferreras, P. (2000). Action Plan for the conservation of the Iberian lynx (Lynx pardinus) in Europe. Council of Europe Publishing, Nature and Environment, No. 111. Strasbourg, France.

Delibes-Mateos, M., Redpath, S. M., Angulo, E., Ferreras, P., and Villafuerte, R. (2007). Rabbits as a keystone species in southern Europe. 
Biological Conservation 137, 149-156. doi:10.1016/j.biocon. 2007.01.024

Edwards, G. P., Dobbie, W., and Berman, D. McK. (2002). Population trends in European rabbits and other wildlife of central Australia in the wake of rabbit haemorrhagic disease. Wildlife Research 29, 557-565. doi:10.1071/WR00097

Elton, C., and Nicholson, M. (1942). The ten-year cycle in numbers of the lynx in Canada. Journal of Animal Ecology 11, 215-244. doi:10.2307/1358

Engeman, R. M. (2005). Indexing principles and a widely applicable paradigm for indexing animal populations. Wildlife Research 32, 203-210. doi:10.1071/WR03120

Fedriani, J. M., Ferreras, P., and Delibes, M. (1998). Dietary response of the Eurasian badger, Meles meles, to a decline of its main prey in the Doñana National Park. Journal of Zoology 245, 214-218.

Fernández, C. (1993). Effect of the Viral Haemorrhagic Pneumonia of the wild rabbit on the diet and breeding success of the golden eagle Aquila chrysaetos (L.). Revue d'Ecologie: La Terre et la Vie 48, 323-329.

Ferrer, M. (2001). 'The Spanish Imperial Eagle.' (Lynx Editions: Madrid.)

Ferrer, M., and Donázar, J. A. (1996). Density-dependent fecundity by habitat heterogeneity in an increasing population of Spanish imperial eagles. Ecology 77, 69-74. doi:10.2307/2265655

Ferrer, M., and Negro, J. J. (2004). The near-extinction of two large European predators: the super-specialists pay a price. Conservation Biology 18, 344-349. doi:10.1111/j.1523-1739.2004.00096.x

Ferreras, P. (2001). Evolución reciente de la distribución y abundancia de mamíferos carnívoros en la comarca de Doñana. In 'V Congress of SECEM.’ Vitoria-Gasteiz. SECEM, pp. 69-70.

Forero, M. G., Donázar, J. A., and Hiraldo, F. (2002). Causes and fitness consequences of natal dispersal in a population of black kites. Ecology 83, 858-872.

García y Bellido, A. (1986). España y los españoles hace dos mil años. Según la geografía de Strabon. Espasa-Calpe, Madrid.

Harris, R. B., and Burnham, K. P. (2002). On estimating wildlife densities from line transect data. Acta Zoologica Sinica 48, 812-818.

Hiraldo, F., Bustamante, J., and Donázar, J. A. (1997). Factores que condicionan la distribución reproductora del milano real (Milvus milvus) en Andalucía: Elaboración de un plan de conservación. Junta de AndalucíaConsejo Superior de Investigaciones Científicas.

Holden, C., and Mutze, G. (2002). Impact of rabbit haemorrhagic disease on introduced predators in the Flinders Ranges, South Australia. Wildlife Research 29, 615-626. doi:10.1071/WR00101

Kufner, M. B. (1986). Tamaño, actividad, densidad relativa y preferencia de hábitat de los pequeños y medianos mamíferos de Doñana, como factores condicionantes de su tasa de predación. Ph.D. Thesis. Universidad Autónoma, Madrid.

LIFE (2002). Recuperación del lince ibérico (Lynx pardinus) en Andalucía (2002-2006). 02/NAT/E/8609.

Lombardi, L., Fernández, N., Villafuerte, R., and Moreno, S. (2003). Habitat related change in rabbit abundance, distribution and activity. Journal of Mammalogy 84, 26-36. doi:10.1644/1545-1542(2003) 084<0026:HRDIRO > 2.0.CO;2

Marchandeau, S., Chaval, Y., and Le Goff, E. (2000). Prolonged decline in the abundance of wild European rabbits Oryctolagus cuniculus and high immunity levels over three years following the arrival of rabbit haemorrhagic disease. Wildlife Biology 6, 141-147.

Marchandeau, S., Aubineau, J., Berger, F., Gaudin, J.-C., Roobrouck, A., Corda, E., and Reitz, F. (2006). Abundance indices: reliability testing is crucial. A field case of wild rabbit (Oryctolagus cuniculus). Wildlife Biology 12, 19-27. doi:10.2981/0909-6396(2006)12[19:AIRTIC]2.0. $\mathrm{CO} ; 2$

Martínez, J. A., and Zuberogoitia, I. (2001). The response of the eagle owl (Bubo bubo) to an outbreak of the rabbit haemorrhagic disease. Journal of Ornithology 142, 204-211. doi:10.1007/BF01651788
Moreno, S., and Villafuerte, R. (1995). Traditional management of scrubland for the conservation of rabbits Oryctolagus cuniculus and their predators in Doñana National Park, Spain. Biological Conservation 73, 81-85. doi:10.1016/0006-3207(95)90069-1

Moreno, S., Villafuerte, R., Cabezas, S., and Lombardi, L. (2004). Wild rabbit restocking for predator conservation in Spain. Biological Conservation 118, 183-193. doi:10.1016/j.biocon.2003.07.020

Mutze, G., Bird, R., Kovaliski, J., Peacick, D., Jennings, S., and Cooke, B. (2002). Emerging epidemiological patterns in rabbit haemorrhagic disease, its interaction with myxomatosis, and their effects on rabbit populations in South Australia. Wildlife Research 29, 577-590. doi:10.1071/WR00100

Norbury, G., Heyward, R., and Parkes, J. (2002). Short-term ecological effects of rabbit haemorrhagic disease in the short-tussock grassland of the South Island, New Zealand. Wildlife Research 29, 599-604. doi:10.1071/WR00085

O’Donoghue, M., Boutin, S., Krebs, C. J., Zulea, G., Murray, D. L., and Hofer, E. J. (1998). Functional responses of coyotes and lynx to the snowshoe hare cycle. Ecology 79, 1193-1208.

Ontiveros, D., and Pleguezuelos, J. M. (2000). Infuence of prey densities in the distribution and breeding success of Bonelli's eagle (Hieraaetus fasciatus): management implications. Biological Conservation 93, 19-25. doi:10.1016/S0006-3207(99)00117-2

Palomares, F. (2001). Comparison of 3 methods to estimate rabbit abundance in a Mediterranean environment. Wildlife Society Bulletin 29, 578-585.

Palomares, F. (2003). The negative impact of heavy rains on the abundance of a Mediterranean population of European rabbits. Mammalian Biology 68, 224-234. doi:10.1078/1616-5047-00088

Palomares, F., Delibes, M., Revilla, E., Calzada, J., and Fedriani, J. M. (2001). Spatial ecology of Iberian lynx and abundance of European rabbits in southwestern Spain. Wildlife Monograph 148, pp. 1-36.

Pech, R. P., Sinclair, A. R. E., Newsome, A. E., and Catling, P. C. (1992). Limits to predator regulation of rabbits in Australia: evidence from predator-removal experiments. Oecologia 89, 102-112. doi:10.1007/ BF00319021

Piorno, V. (2006). Gestión cinegética y conservación del conejo de monte. Ph.D. Thesis, Universidad de Vigo, Spain.

Poole, D. W., Cowan, D. P., and Smith, G. C. (2003). Developing a census method based on sight counts to estimate rabbit (Oryctolagus cuniculus) numbers. Wildlife Research 30, 487-493. doi:10.1071/WR02014

Rau, J. R. (1987). Ecología del zorro, Vulpes vulpes (L.) en la Reserva Biológica de Doñana, SO de España. Ph.D. Thesis, Universidad de Sevilla, Spain.

Rödel, H. G., Bora, A., Kaiser, J., Kaetzke, P., Khaschei, M., and von Holst, D. (2004). Density dependent reproduction in the European rabbit: a consequence of individual response and age-dependent reproductive performance. Oikos 104, 529-539. doi:10.1111/j.0030-1299.2004. 12691. $\mathrm{x}$

Rodríguez, A., and Delibes, M. (2003). Population fragmentation and extinction in the Iberian lynx. Biological Conservation 109, 321-331. doi:10.1016/S0006-3207(02)00158-1

Rodríguez, A., and Delibes, M. (2004). Patterns and causes of non-natural mortality in the Iberian lynx during a 40 -year period of range contraction. Biological Conservation 118, 151-161. doi:10.1016/j.biocon. 2003.07.018

Rosell, J. M. (2000). Enfermedades del conejo. Editorial Mundi-Prensa. Madrid, Barcelona, México.

Saunders, G., Choquenot, D., Mcllroy, J., and Packwood, R. (1999). Initial effects of rabbit hemorrhagic disease on free-living rabbit (Oryctolagus cuniculus) populations in central-western New South Wales. Wildlife Research 26, 69-74. doi:10.1071/WR98031

Solomon, M. E. (1949). The natural control of animal populations. Journal of Animal Ecology 18, 1-35. doi:10.2307/1578 
Sumption, K. J., and Flowerdew, J. R. (1985). The ecological effects of the decline of rabbits (Oryctolagus cuniculus L.) due to myxomatosis. Mammal Review 15, 151-186.

Thomas, L., Laake, J. L., Durry, J. F., Buckland, S. T., Borchers, D. L., et al. (1998). Program Dros. Inf. Serv.TANCE 3.5. Research Unit for Wildlife Population Assessment, University of St Andrews, UK. Available from http://www.ruwpa.st-and.ac.uk/distance.

Thompson, W. L., White, G. C., and Gowan, C. (1998). 'Monitoring Vertebrate Populations.' (Academic Press: San Diego, CA.)

Travaini, A., Delibes, M., Ferreras, P., and Palomares, F. (1997). Diversity abundance or rare species as a target for the conservation of mammalian carnivores: a case study in southern Spain. Biodiversity and Conservation 6, 529-535. doi:10.1023/A:1018329127772

Trout, R., and Tittensor, A. M. (1989). Can predators regulate wild rabbit Oryctolagus cuniculus population density in England and Wales? Mammal Review 19, 153-173.

Valverde, J. A. (1958). An ecological sketch of the Coto Doñana. British Birds 51, 1-23.

Valverde, J. A. (1960a). La population d'aigles imperiaux de Marismas du Guadalquivir: son evolution depuis siecle XX. Alauda 28, 20-26.

Valverde, J. A. (1960b). Vertebrados de las Marismas del Guadalquivir. Archivos Instituto Aclimatación de Almería 9, 1-168.

Valverde, J. A. (1967). Estructura de una comunidad de vertebrados terrestres. Monografías de la Estación Biológica de Doñana 1, 1-218.

Villafuerte, R. (1994). Riesgo de predación y estrategias defensivas del conejo, Oryctolagus cuniculus, en el Parque Nacional de Doñana. Ph.D. Thesis, Universidad de Córdoba, Spain.

Villafuerte, R., Kufner, M. B., Delibes, M., and Moreno, S. (1993). Environmental factors influencing the seasonal daily activity of the European rabbit (Oryctolagus cuniculus) in a Mediterranean area. Mammalia 57, 341-347.
Villafuerte, R., Calvete, C., Gortázar, C., and Moreno, S. (1994). First epizootic of Rabbit Haemorrhagic Disease (RHD) in free living populations of Oryctolagus cuniculus at Doñana National Park SW Spain. Journal of Wildlife Diseases 30, 176-179.

Villafuerte, R., Calvete, C., Blanco, J. C., and Lucientes, J. (1995). Incidence of viral hemorrhagic disease in wild rabbits populations in Spain. Mammalia 59, 651-659.

Villafuerte, R., Lazo, A., and Moreno, S. (1997). Influence of food abundance and quality on rabbit fluctuations: conservation and management implications in Donana National Park (SW Spain). Revue d'Ecologie: La Terre et la Vie 52, 345-356.

Viñuela, J., and Veiga, J. P. (1992). Importance of rabbits in the diet and reproductive success of black kites in southwestern Spain. Ornis Scandinavica 23, 132-138. doi:10.2307/3676440

Viñuela, J., and Villafuerte, R. (2003). Predators and rabbits in Spain: a key conflict for conservation of European raptors. In 'Birds of prey in a Changing Environment'. (Eds D. B. M. Thompson, S. Redpath, A. Fielding, M. Marquis and C. A. Galbraith.) (The Stationery Office: Edinburgh.)

Virgós, E., Cabezas-Díaz, S., and Lozano, J. (2007). Is the wild rabbit (Oryctolagus cuniculus) a threatened species in Spain? Sociological constraints in the conservation of species. Biodiversity and Conservation 16, 3489-3504.

Zapata, S. C., Travaini, A., and Delibes, M. (1998). Reproduction of the red fox, Vulpes vulpes, in Doñana, southern Spain. Mammalia 62, 139-142.

Manuscript received 24 October 2006, accepted 31 October 2007 